Diabetologia 10, 89-91 (1974)

(C) by Springer-Verlag 1974

\title{
Histopathological Changes in the Placenta of Streptozotocin Induced Diabetic Rats
}

\author{
R. Prager ${ }^{1}$, A. Abramovici ${ }^{2}$, E. Liban ${ }^{2}$, and Z. Laron ${ }^{1 *}$ \\ Institute of Pediatric and Adolescent Endocrinology ${ }^{1}$ and Laboratory of Developmental Pathology ${ }^{2}$, Beilinson Medical \\ Center, Petach Tikva and Departments of Pediatrics Physiology and Pathology, Sackler Medical School of Tel-Aviv \\ University
}

Received: June 15, 1973, and in revised form: November 20, 1973

Summary. Induction of diabetes by one intraperitoneal dose of Streptozotocin $(50 \mathrm{mg} / \mathrm{kg}$ ), 8 to 12 days before mating, was found to produce severe degenerative cystic lesions in the spongiosa layer of the placenta. The administration of Streptozotocin, 16-24 days prior to mating, showed non significant changes in the placenta. The morphologic changes observed might well explain the correlation between the bigger placentas and the smaller fetuses found in the Streptozotocin treated rats. STR administered before mating had no teratogenic effect on the fetuses.

Key words: Experimental diabetes, streptozotocin, placenta.
Communications of the effect of Streptozotocin (STR) induced diabetes on placental and fetal alterations are very scarce and concern only few biochemical and gross morphometric data $[1-3]$. The present investigation was designed to extend these studies on the histopathological changes of placenta after a single dose of STR, given to adult female rats before mating.

\section{Material and Methods}

Eighteen adult female Wistar rats, weighing approximately $160 \mathrm{~g}$ received a single intraperitoneal injection of $50 \mathrm{mg} / \mathrm{kg}$ Streptozotocin (Upjohn Co., Batch No. 9681 - GGS - 118 FI) in buffered citrate solution at $\mathrm{pH}$ 4.6. The food, standard rat pellets and water intake, were ad libitum for both the experimental, as well as for ten control animals. Non fasting glycaemia was determined in blood of adult rats obtained from the tails on day 3 or 4 following the STR injection by the glucose oxidase method of Kingsley et al. [4]. Diabetic rats were considered only those in which the blood sugar values were at least $200 \mathrm{mg} / 100 \mathrm{ml}$ or more (compared to a concentration of $60-80 \mathrm{mg} / 100 \mathrm{ml}$ in the control rats). Two out of 18 rats were drug resistant as no hyperglycaemia could be obtained. Frequently, glycaemia reached levels of $300-400 \mathrm{mg} / 100 \mathrm{ml}$. Glycosuria was estimated qualitatively by Diastix (Ames) at various stages of the experiment. Intense glycosuria persisted till the end of pregnancy in all the diabetic rats.

The rhythm and length of the estrous cycle was controlled by daily vaginal smears. The day of appearance of sperm in the smear after mating with normal adult males was considered as day one of pregnancy. According to the time of mating after the STR injec-

* This work was supported by: Grants "Harry C. Bernard" and "Lea Segal Research Funds". tion, the animals were subdivided into two treatment groups.

a) Acute cases (11 rats), when pregnancy was initiated up to 12 days after the drug administration.

b) Subacute cases (5 rats), when mating occurred between 16 to 24 days after STR.

c) The third group consisting of 10 untreated female rats matched by weight, served as control.

On day 20 of pregnancy, the rats were killed and fetuses and placentas were examined and weighed. Pieces of placental bed were taken and fixed in $10 \%$ buffered formalin solution, Carnoy and Helly fixatives. The histological sections of $6-8 \mu$ thickness were stained with haematoxylin, periodic acid Schiff (PAS) and Mallory trichrome stains. Whole embryos were fixed in $10 \%$ buffered formalin solution and examined macroscopically for eventual congenital anomalies by serial transversal sections (Wilson's slices) or by skeletal staining with alizarin red and subsequent clearing with $\mathrm{KOH}$ solution.

\section{Results}

The estrous cycles were as regular in the treated as in the control rats and no difficulty in mating them was found. The placental weight on the 20 th day of pregnancy was greater $(0.75 \pm 0.06 \mathrm{~g})$ in the diabetic rats than in the controls $(0.55 \pm 0.10 \mathrm{~g})$. However, the fetal weight on day 20 was smaller in the STR treated rats $(3.03 \pm 0.22 \mathrm{~g})$ as compared to the control rats $(3.59 \pm 0.16 \mathrm{~g})$. No gross malformations of the skeleton or internal organs were observed either in the treated group or in the control group.

Pathological changes in the placenta were observed mainly in the spongiosa region while the labyrinthic region and the chorioallantoic membrane were normal. 
The morphological lesions were classified as follows:

Group 1. "Normal". The control full term placenta showed a mild dilatation of the sinusoids in the spongiosa (Fig. 1). Higher magnification revealed that the cytotrophoblastic cells were arranged in a chuster pattern, while the giant cells were dispersed among these clusters or arranged towards the maternal side of the placenta: The labyrinthic zone showed that the villi containing fetal blood vessels enclosed some nucleated erythrocytes, whereas outside the villi, the maternal sinusoids contained non nucleated erythrocytes. Such a pattern was found in 8 control rats, 2 drug resistant rats and also in the majority of animals (4/5 rats) of the subacute treated group (16-24 days before mating).
Table 1 correlates the type of lesion with the mean blood sugar level of each group.

\section{Discussion}

In this study the diabetogenic effect of a single dose of Streptozotocin (STR) given intraperitoneally to adult female rats before mating was confirmed, as well as the fetal and placental morphometric changes reported by others, $[1-3]$. Yet, probably due to the low STR toxicity in the dose employed, neither variations in the estrous cycle length nor difficulty in mating were observed, as described previously [5-10].

The induced placental lesions, limited to the spongiosa zone and characterized by cyst formation

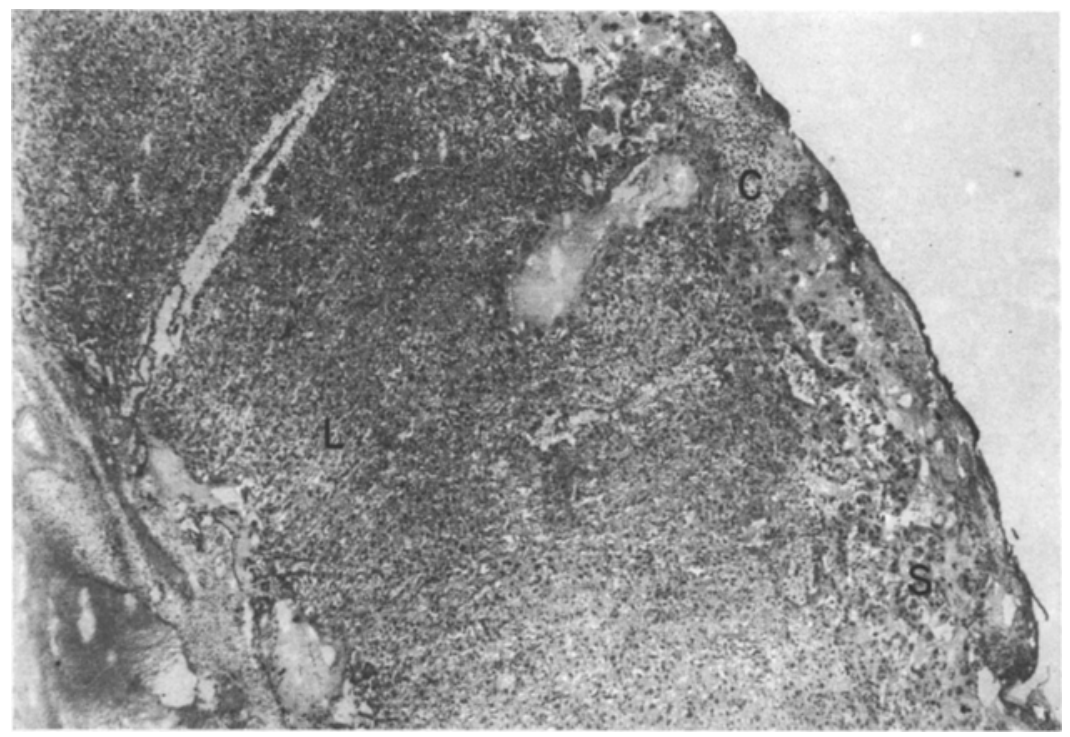

Fig. 1. Normal rat placenta at 20th day of gestation. Clusters of small cytotrophoblasts (C) and isolated giant cells are seen in the spongiosa region (S). Moderate dilatation of blood sinusoids is present. The labyrinth region (L) occupies the main part of the placenta. $H \& \mathrm{E}$ stain $(40 \times)$

Group 2. "Mild lesions". This group is characterized by the presence of solitary cystic formations in the spongiosa region, containing some cellular debris, and eosinophilic material. The size of the cysts was variable and they revealed well defined borders. The trophoblastic giant cells were few and some of them, specially in the vicinity of the cysts, showed some cytoplasmatic degeneration and increased nuclear basophilia. These changes were found in 3 acutely treated rats, in one subacute and in 2 control animals.

Group 3. "Severe changes". These lesions were characterized by an increase in the number and size of cysts in the spongiosa region. The cysts were separated by thin acellular fibrous septa and contained a granular eosinophillic material. Sometimes they coalesced, thus forming a common multilocular formation. The giant cells showed more advanced degenerative changes than in the previous group, with pyknotic nuclei and karyorrhexis. These lesions (Fig. 2) were observed in 8 out of 11 acutely treated animals.
Table 1. Correlation between the degree of placental lesion and mean blood sugar level

\begin{tabular}{|c|c|c|c|c|c|c|}
\hline & \multicolumn{2}{|c|}{$\begin{array}{l}\text { Group } 1 \\
\text { "Normal" }\end{array}$} & \multicolumn{2}{|c|}{$\begin{array}{l}\text { Group } 2 \\
\text { "Mild Lesions" }\end{array}$} & \multicolumn{2}{|c|}{$\begin{array}{l}\text { Group } 3 \\
\text { "Severe Lesions", }\end{array}$} \\
\hline & & $\begin{array}{l}\text { Mean } \\
\text { Glueose } \\
\text { mg\% }\end{array}$ & No. & $\begin{array}{l}\text { Mean } \\
\text { Glucose } \\
\mathrm{mg} \%\end{array}$ & $\overline{\text { No. }}$ & $\begin{array}{l}\text { Mean } \\
\text { Glucose } \\
\text { mg\% } \%\end{array}$ \\
\hline \multicolumn{7}{|l|}{$\begin{array}{l}\text { Normal } \\
\text { rats }\end{array}$} \\
\hline $\begin{array}{c}10 \\
\text { Acute }\end{array}$ & 8 & 66 & 2 & 58 & - & - \\
\hline $\begin{array}{l}11 \\
\text { Subacute }\end{array}$ & - & - & 3 & 256 & 8 & 267 \\
\hline $\begin{array}{l}5 \\
\text { Resistant }\end{array}$ & 4 & 244 & 1 & 312 & - & - \\
\hline 2 & 2 & 70 & - & - & - & - \\
\hline
\end{tabular}

and destruction of the cytotrophoblastic cells of this region, have to the best of our knowledge not yet been reported. For the present we were not able to establish a correlation between the degree of the hyperglycaemia 
and the intensity of the pathological changes in the placenta, due to the insufficient number of rats. Nevertheless, even if not directly related to them, the metabolic events in diabetes may have affected the development and degree of these abnormal placental changes after STR. It is noteworthy that all the severe changes were found selectively in the acute treatment group, while both in the control rats as well as in the resistant group there were none or only minimal changes. The finding that the acute STR treated group showed more severe changes than the subacute group cannot yet be explained. The short half life of STR [11], might exclude a possible direct effect on the placenta. Further studies are now in progress in order to reveal the relation between placenta and uterine tissue, especially the blood vessels which are known to be affected in diabetic pregnancy.
3. Sybulski, S., Maugham, G.B.: Use of streptozotocin as a diabetic agent in pregnant rats. Endocrinology 89, 1537-1540 (1972)

4. Kingsley, G.R., Getchell, G.: Direct ultramicro glucose oxidase method for determination of glucose in biologic fluids. Clin. Chem. 6, 466--475 (1960)

5. Foglia, V.G.. Cattaneo de Peralta Ramos, M., Toarra, R., Rivera Cortés, L.: La fertilité chez la ratte pancreatoprive et les alterations anatomo-pathologiques trouvées dans l'uterus et l'ovaire. Compt. Rend. Soc. Biol. (Paris) 162, 2013 (1968)

6. Foglia, V.G., Cattaneo de Peralta Ramos, M., Ibarra, R., Rivera Cortés, L.: Alterations des foetus et des placentas au cours de la grossesse chez la ratte blanche pancreatectomisée. Compt. Rend. Soc. Biol. (Paris) 162, $2018(1968)$

7. Chieri, R.A., Pivetta, O.H., Foglia, V.G.: Altered ovulation pattern in experimental diabetes. Fertil. and Steril. 20, $661-666$ (1969)

8. Foglia, V.G., Chieri, R.A., Cattaneo de Peralta Ra-

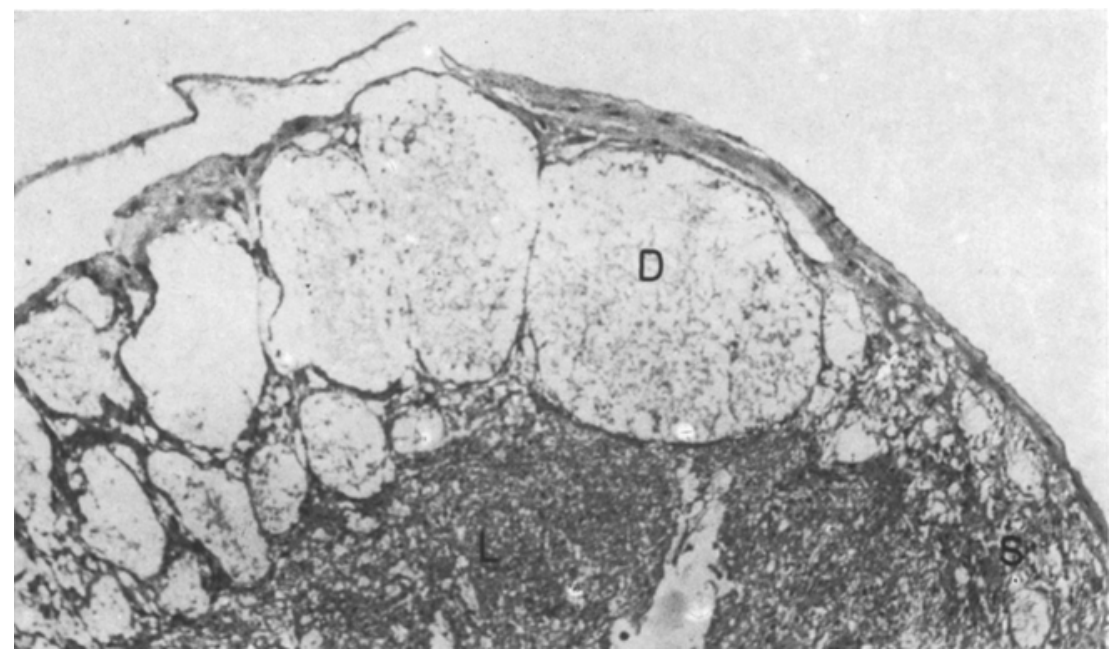

Fig. 2. Severe placental lesion in the spongiosa region (S) in an acute STR treated rat. The lesion is characterized by severe cystic dilatations (D) of various sizes containing granular eosinophilic material. The cysts can be well defined or coalesced together. The labyrinth region (L) is normal but reduced in size. H \& $\mathrm{E}$ stain $(40 \times)$

The placental lesions described herein might lead to an impairment of the placental nutrition and thus explain the decreased fetal weight. The increased placental weight might be the consequence of the cysts filled with transudate. It was also shown that the STR treatment prior to mating had no teratogenic effects on the diabetic offsprings.

Further studies to define the etiology of the placental lesions by STR induced diabetes in rats including biochemical studies are in progress.

\section{References}

1. Golob, E.: Streptozotocin diabetes bei der schwangeren Ratte. Z. Geburtsh. Gynäk. 171, 18-38(1969)

2. Golob, E.K., Rishi, S., Becker, K.L., Moore, Ch.: Streptozotocin diabetes in'pregnant and non pregnant rats. Metabolism 19, 1014-1019 (1970) mos, M. : Mechanisms of disturbances during pregnancy in diabetic female rats. Horm. Metab. Res. 2, 76$80(1970)$

9. Lazarow, A., Heggestad, C.B.: Offsprings of animals with experimental diabetes, in "Early Diabetes", p. 229-237, (Eds. Camerini-Davalos, R., Cole, H.S.) New York: Academic Press 1970

10. Foglia, V.G.: Fetuses and newborns of $95 \%$ pancreatectomized female rats. In: "Early Diabetes", p. 221-227, (Eds. Camerini-Davalos, R., Cole, H.S.). New York: Academic Press 1970

11. Rerup, C.C.: Drugs producing diabetes through damage of insulin secreting cells. Pharmacol. Rev. 22, $485-518(1970)$

Prof. Z. Laron

Institute of Pediatric and

Adolescent Endocrinology

Beilinson Hospital

Petach Tikva

Israel 